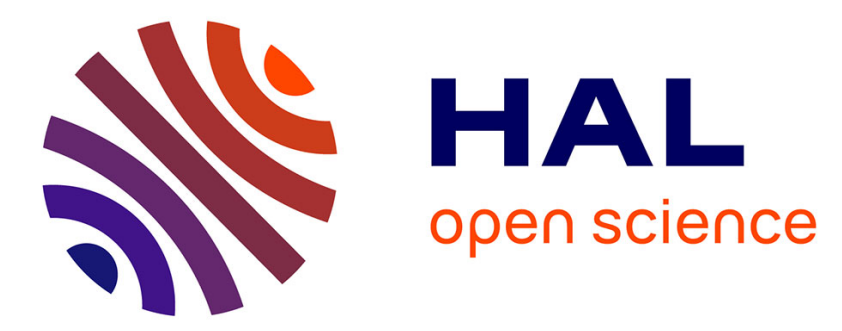

\title{
Lack of lethal and sublethal effects of Cry1Ac Bt-toxin on larvae of the stingless bee Trigona spinipes
}

\author{
Maria Lima, Carmen Pires, Raul Guedes, Lucio Campos
}

\section{To cite this version:}

Maria Lima, Carmen Pires, Raul Guedes, Lucio Campos. Lack of lethal and sublethal effects of Cry1Ac Bt-toxin on larvae of the stingless bee Trigona spinipes . Apidologie, 2012, 44 (1), pp.21-28. 10.1007/s13592-012-0151-z . hal-01201268

\section{HAL Id: hal-01201268 \\ https://hal.science/hal-01201268}

Submitted on 17 Sep 2015

HAL is a multi-disciplinary open access archive for the deposit and dissemination of scientific research documents, whether they are published or not. The documents may come from teaching and research institutions in France or abroad, or from public or private research centers.
L'archive ouverte pluridisciplinaire $\mathbf{H A L}$, est destinée au dépôt et à la diffusion de documents scientifiques de niveau recherche, publiés ou non, émanant des établissements d'enseignement et de recherche français ou étrangers, des laboratoires publics ou privés. 


\title{
Lack of lethal and sublethal effects of Cry1Ac Bt-toxin on larvae of the stingless bee Trigona spinipes
}

\author{
Maria Augusta P. Lima ${ }^{1}$, Carmen Silvia S. Pires ${ }^{2}$, Raul Narciso C. Guedes ${ }^{3}$, \\ Lucio Antonio O. CAMPOS ${ }^{4}$ \\ ${ }^{1}$ Departamento de Biologia Animal, Universidade Federal de Viçosa, Viçosa, MG 36570-000, Brazil \\ ${ }^{2}$ EMBRAPA Recursos Genéticos e Biotecnologia, Pq Estação Biológica, Asa Norte, Cx. Postal 02372, Brasília, \\ DF 70849-970, Brazil \\ ${ }^{3}$ Departamento de Entomologia, Universidade Federal de Viçosa, Viçosa, MG 36570-000, Brazil \\ ${ }^{4}$ Departamento de Biologia Geral, Universidade Federal de Viçosa, Viçosa, MG 36570-000, Brazil
}

Received 20 January 2012 - Revised 18 May 2012 - Accepted 4 June 2012

\begin{abstract}
Stingless bees, particularly Trigona spinipes, are important pollinators in tropical ecosystems and are potentially affected by environmental contaminants. In this study, we tested the possible negative effects on T. spinipes larvae of the ingestion of a diet contaminated with CrylAc Bt-toxin. This toxin is expressed in genetically modified cotton plants. A method of rearing stingless bee larvae is described in this paper. The larvae were provided with either pure larval diet, diluted larval diet, or larval diet diluted in a Cry1Ac solution compatible with the lethal pest-exposure level $(50 \mu \mathrm{g} / \mathrm{mL})$. Cry1 Ac ingestion did not impair the development of worker larvae, but the diluted diet slightly increased larval mortality. These results indicate that harmful effects on stingless bee larvae due to the ingestion of pollen-expressed Cry1Ac toxin are unlikely under field conditions.
\end{abstract}

Bacillus thuringiensis toxin / transgenic plants / environmental impact / native pollinator / risk assessment

\section{INTRODUCTION}

The cultivation of genetically modified (GM) crops is expanding rapidly worldwide, particularly in Brazil. The increase in Brazil's cultivated area over the past few years is the highest in the world (James 2011). Transgenic cotton expressing Bacillus thuringiensis toxins $(\mathrm{Bt}$ cotton) was first planted in 1996 and is currently the third largest crop cultivated worldwide (James 2011). Due to the high levels of expression of the Cry1Ac toxin in the pollen of $\mathrm{Bt}$ cotton, the pollinators foraging on this crop

Corresponding author: M.A.P. Lima, maugusta@ufv.br

Manuscript editor: Monique Gauthier face an increased risk of exposure to the toxin (Han et al. 2010).

Cotton flowers are frequently visited by several bee species to harvest pollen and nectar (Arpaia et al. 2006). Foraging for these resources on Bt cotton may potentially affect these species, which are important because of their pollination service for most terrestrial ecosystems, including agroecosystems (Malone et al. 2002; Klein et al. 2007). Therefore, the environmental risk analysis of $\mathrm{Bt}$ cotton should include an assessment of the potentially harmful effects of ingested pollen and nectar containing the expressed Bt protein Cry1Ac. This assessment should focus on a worst-case scenario, in which the species facing a high risk of exposure should be subjected to the highest doses that are possible in practice (Wilkinson 2004). 
The honey bee Apis mellifera Linnaeus is the most frequently used pollinator in risk assessment studies of $\mathrm{Bt}$ toxins due to its economic value as a pollinator. There are few studies assessing the toxicological effect of $\mathrm{Bt}$ toxins on bee larvae, even in the honey bee (Hanley et al. 2003; Babendreier et al. 2004; Lerhman 2007; Lima et al. 2011). Nevertheless, the extrapolation of the results of such studies to other bee species is questionable due to the nutritional, behavioral, and physiological differences among bee species.

Stingless bees (Hymenoptera: Apidae: Meliponini), a group of eusocial bees, are important pollinators in tropical and agricultural ecosystems (Slaa et al. 2006; Dick 2001) and they are similar to most of the solitary bees in that they store large amounts of pollen in their nests (Wcislo and Cane 1996). The pollen is one of the primary components of the larval diet of meliponines (Velthuis et al. 2003) and is the primary protein source for stingless (and solitary) bee larvae. The nutrition furnished by high-protein pollen produces larger adult workers, which are generally considered more efficient foragers and pollinators (Klostermeyer et al. 1973; Pyke 1978; Quezada-Euán et al. 2011).

Unlike honey bee larvae, which are fed on glandular secretions produced by the nurse bees (Babendreier et al. 2004), stingless bee larvae ingest large amounts of pollen. Therefore, the risk of exposure of stingless (and solitary) bee larvae to Cry toxins is higher than that of honey bee larvae and should be assessed. Unfortunately, despite the ecological and economic importance of stingless bees in tropical areas, there are no studies in stingless bees assessing the toxicity of GM plants expressing Bt toxins.

Toxicological assessments of Bt proteins expressed in GM plants in stingless bees are needed, with a primary focus on the larval stage. The development of suitable research protocols is necessary to perform such assessments. Tests with purified toxins are an initial step required for the risk assessment of GM plants in bees (Malone et al.
2004). Because foraging stingless bees may collect pollen from Bt plants and feed this pollen to the larvae, these larvae can potentially suffer lethal and sublethal effects from such exposure. The present study was conducted to test this hypothesis. The objectives of the study were to develop a suitable methodology to assess the effects of Bt toxin from GM plants on the worker larvae of stingless bees and to assess the risk of ingested Cry1Ac Bt-toxin on larval development. The stingless bee Trigona spinipes Fabricius was used as a model because of its wide distribution and frequent occurrence on cotton flowers in Brazil. These characteristics make it a potential target for the expressed toxin (Arpaia et al. 2006). In addition, caste determination in this species is dependent on the amount of food ingested by the females (Buschini and Campos 1995). The colonies are usually large, showing a high level of recruitment of nestmates for foraging and efficient exclusion of competing pollinator species (Almeida and Laroca 1988; Nieh et al. 2004a,b, 2005; Lichtenberg et al. 2011). These traits further increase the risk of exposure of the larvae of this species to the $\mathrm{Bt}$ toxins expressed in the pollen and nectar of GM cotton plants, and this increased risk serves to justify the present study.

\section{MATERIALS AND METHODS}

\subsection{Insects}

Five colonies of the stingless bee species $T$. spinipes were collected in the field in Viçosa County (MG, Brazil; $20^{\circ} 45^{\prime} \mathrm{S}$ and $42^{\circ} 52^{\prime} \mathrm{W}$ ) from January through June 2006 and maintained under field conditions at the experimental apiary of the Federal University of Viçosa (Viçosa, MG, Brazil). These colonies were used to collect larval diet and eggs for the toxicological bioassays.

The bioactivity of the CrylAc Bt-toxin was verified following Lima et al. (2011) using the velvetbean caterpillar Anticarsia gemmatalis (Hübner) (Lepidoptera: Noctuidae), which is susceptible to this toxin. The caterpillars were reared 
on a solid artificial diet based on beans and wheat germ under controlled conditions of $25 \pm 2{ }^{\circ} \mathrm{C}$ temperature, $70 \pm 5 \% \mathrm{RH}$ and $12 \mathrm{~h}$ photoperiod.

\subsection{Insecticidal bioactivity of Cry1Ac}

The toxin Cry1Ac used was obtained from the Biochemistry Department of Case Western Reserve University (Cleveland, OH, USA). The purified toxin was stored in lyophilized form at $-15{ }^{\circ} \mathrm{C}$ and eventually dissolved in double-distilled (sterile) water to be mixed with the insect diet for the bioassays. The activity of the toxin was tested on second-instar velvetbean caterpillars. These caterpillars were continuously exposed to the $\mathrm{Bt}$ toxincontaminated diet for 7 days at $34 \pm 1{ }^{\circ} \mathrm{C}$ and $98 \pm$ $2 \% \mathrm{RH}$, environmental conditions typical for rearing the larvae of $T$. spinipes. This environment simulated the conditions under which stingless bee larvae would be exposed to the toxins. The caterpillars were exposed to each of the following treatments, placed on the surface of the larval diet with a micropipette: (a) water; (b) $50 \mu \mathrm{g}$ of CrylAc toxin diluted in $1 \mathrm{~mL}$ of water, an amount that is toxic to caterpillars according to Cerda et al. (2003); (c) the larval diet of T. spinipes; and (d) the larval diet of $T$. spinipes, additionally containing $50 \mu \mathrm{g}$ of Cry1Ac toxin diluted in $1 \mathrm{~mL}$ of water. Five replicates with 30 caterpillars each were used in the bioassay, and mortality was assessed after 7 days of exposure and used as an indication of the insecticidal activity of the Cry $1 \mathrm{Ac}$ Bt-toxin available for the stingless bee study.

\subsection{Rearing stingless bee larvae}

The larval rearing protocol for T. spinipes was adapted from Buschini and Campos (1995). The larvae were individually maintained in artificial cells made with honey bee wax and placed on polyethylene microplates (with rounded bottom wells). Each larval cell was maintained in a microplate well and covered with a circular (honey bee) wax cap resembling the natural brood chamber. The larval diet was collected from the same hives from which the larvae were tested in each bioassay. The brood chambers with eggs were removed from the hives, and the eggs were transferred to artificial cells filled with $36 \mu \mathrm{L}$ of diet to allow the worker larva to complete its development. The polyethylene microplates containing the artificial brood chambers were maintained at $34 \pm 1{ }^{\circ} \mathrm{C}, 98 \pm 2 \% \mathrm{RH}$ and $24 \mathrm{~h}$ scotophase until the end of the feeding period. The artificial brood chambers were subsequently removed and transferred to conditions of $34 \pm 1{ }^{\circ} \mathrm{C}$, $70 \pm 10 \% \mathrm{RH}$, and $24 \mathrm{~h}$ dark to simulate natural conditions (Sakagami 1981). All materials used to collect the larvae, to store and collect the larval diet, and to set up the bioassays were autoclaved or sterilized in germicidal UV light in a biosafety chamber.

\subsection{Determination of pollen ingestion by stingless bee larvae}

The values of the amount of pollen ingested per larva and the amount of toxin present in the pollen were used to estimate the amount of toxin ingested by the larva. Therefore, it is necessary to determine the proportion of pollen contained in the larval diet of $T$. spinipes. We performed this determination with brood chambers containing eggs and collected from four hives of $T$. spinipes. The chambers were opened with forceps, and the eggs were removed using a metal scalpel. The larval diet was subsequently removed using a suction pump. We collected $30 \mathrm{~mL}$ of larval diet from each hive and distributed the diet in six centrifuge tubes (5 $\mathrm{mL}$ per tube), which were centrifuged at $2,500 \mathrm{rpm}$ for $10 \mathrm{~min}$ to separate the pollen from the liquid portion of the larval diet. The liquid was discharged, and the pollen left in the tube was dried at $60{ }^{\circ} \mathrm{C}$ until complete dehydration to determine its dry mass on an analytical balance.

\subsection{Cry1Ac bioassay with stingless bee larvae}

Eggs of $T$. spinipes obtained from hives maintained at the experimental apiary, as previously described, were individually transferred to the artificial brood chambers filled with larval diet according to the following treatments: (a) pure larval diet (36 $\mu \mathrm{L}$; control); (b) diluted larval diet $(35.1 \mu \mathrm{L}$ pure larval diet $+0.9 \mu \mathrm{L}$ sterile water; diluted control); and (c) larval diet diluted in a Cry1Ac solution $(35.1 \mu \mathrm{L}$ 
$\operatorname{diet}+0.9 \mu \mathrm{L}$ sterile water solution containing Cryl Ac at $50 \mu \mathrm{g}$ toxin per milliliter of diet; $1.8 \mu \mathrm{g}$ toxin/larva). This toxin concentration was used because it was recognized as a toxic level for the velvetbean caterpillar (A. gemmatalis) (Cerda et al. 2003) and because it was in excess of the maximum possible field exposure estimated in terms of the potential pollen ingestion by stingless bee larvae. Each treatment was replicated five times with 40 larvae per treatment collected from the five available hives (a total of 200 larvae per treatment).

The daily mortality and developmental time of the larvae and pupae were recorded until adult emergence. The newly emerged adult bees were collected and chilled $\left(-4{ }^{\circ} \mathrm{C}\right)$ for $7 \mathrm{~min}$ for body mass determination on an analytical balance. The newly emerged bees were subsequently fixed in a methanol/ acetic acid solution (3:1) for $24 \mathrm{~h}$ and maintained in $70 \%$ ethanol for morphometric determinations with a stereomicroscope equipped with a micrometric ocular. The morphological traits measured were the head width (the maximum distance between the outer edges of the compound eyes) and the intertegular distance (the minimum distance between the edges of the tegulae) (Bosch and Vicens 2002). The measurements were converted to millimeters.

\subsection{Statistical analyses}

The mortality of the velvetbean caterpillar was subjected to an analysis of variance and a Tukey-Kramer test $(P<0.05)$ whenever appropriate after verifying normality and homeoscedasticity (PROC GLM and PROC UNIVARIATE; SAS Institute 2008). A survival analysis was conducted to recognize potential differences in mortality during development among diet treatments. The survival curves were obtained from Kaplan-Meier estimates generated from the proportion of larvae surviving daily from the start until the end of the experiment (PROC LIFETEST; SAS Institute 2008). The bees surviving until adult emergence (35th day) were treated as censored data (Allison 1998). The survival curves of each treatment were compared with a Cox regression (PROC PHREG; SAS Institute 2008). The developmental time, body mass, and morphometric traits were subjected to an analysis of variance after an evaluation of normality and homeoscedasticity (PROC GLM and PROC UNIVARIATE; SAS Institute 2008). The body mass and morphometric traits were also subjected to a correlation analysis (PROC CORR; SAS Institute 2008). The graphics were plotted with GraphPad Prism 5 software (Motulsky 2007).

\section{RESULTS}

\subsection{Cry1Ac insecticidal bioactivity towards caterpillars}

The bioactivity of the Cry1Ac Bt-toxin was demonstrated by the mortality of the velvetbean caterpillar (A. gemmatalis), which was statistically significant $\left(F_{2,12}=244.2, P<0.001\right.$; Figure 1). The toxin Cry1Ac caused significantly higher caterpillar mortality (about $90 \%$ ) than the control treatments mixed with water only or added to the pure larval diet of $T$. spinipes. Therefore, the toxin used in our study was active, and the larval diet of T. spinipes did not compromise this toxic activity.

\subsection{Rearing of stingless bee larvae}

The rearing protocol used for $T$. spinipes employing artificial brood chambers made with honey bee wax on a polyethylene microplate was suitable for rearing the worker larvae of T. spinipes. A survival value of $91 \%$ was achieved with the pure larval diet (Figure 2). In addition, no pupal or adult malformations were observed. Superior age standardization was achieved through the use of eggs instead of larvae to perform the bioassays.

\subsection{Determination of pollen ingestion by the stingless bee larvae}

The concentration of dried pollen in the larval diet of $T$. spinipes varied significantly among the colonies $\left(F_{4,25}=12.9, P<0.001\right)$. The highest pollen concentration observed was $11.5 \pm 0.3 \%$ of the diet mass. Based on the premise of the worst-case scenario, this content was used to estimate the minimum concentration of Cry1Ac to be furnished to the larvae of $T$. spinipes. Experiments with $\mathrm{Bt}$ cotton show levels of Cry1Ac expression in the pollen of up to 


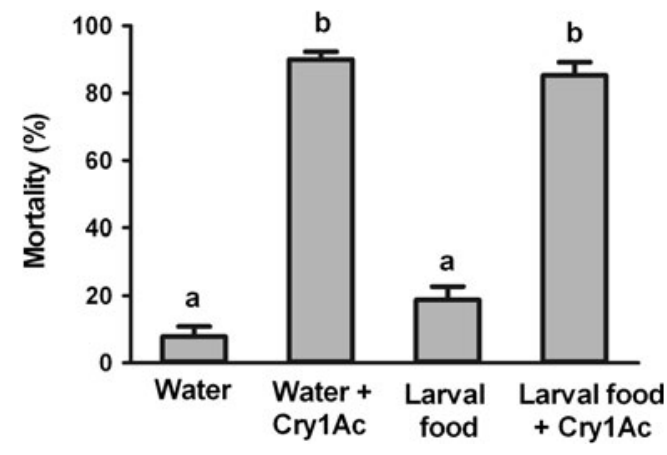

Figure 1. Mortality $( \pm$ SEM) (\%) of velvetbean caterpillars (Anticarsia gemmatalis) fed with artificial diet containing water (control), diluted Cry1Ac toxin (50 $\mu \mathrm{g} /$ larva), larval diet of Trigona spinipes, or larval diet of $T$. spinipes mixed with diluted Cry1Ac $(50 \mu \mathrm{g} /$ larva). Mortality was assessed after 7 days of exposure. Histogram bars with the same letter are not significantly different (ANOVA followed by TukeyKramer test; $P<0.001)$.

$600 \mathrm{ng} / \mathrm{g}$ (Greenplate 1997). The worker larvae of T. spinipes ingest $36 \mu \mathrm{L}$ of diet during their development (Buschini and Campos 1995). Therefore, because the pollen represents approximately

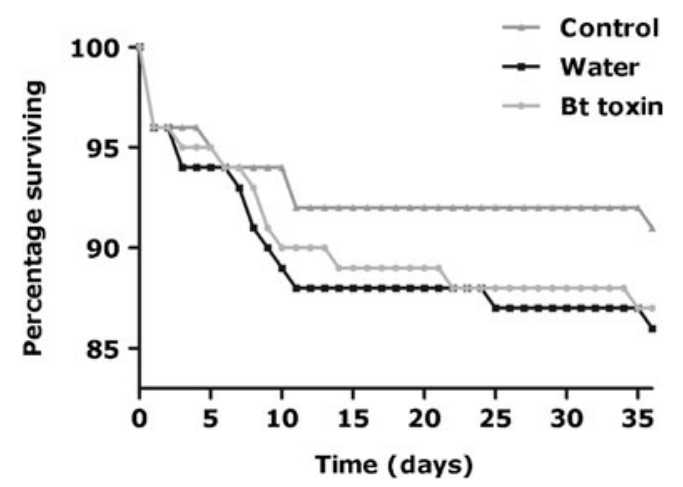

Figure 2. Survival curves of workers of the stingless bee Trigona spinipes fed with larval diet (control), diluted larval diet, and larval diet mixed with a solution of $\mathrm{Bt}$ toxin (each treated larva received $1.8 \mu \mathrm{g}$ of Cry1Ac). Kaplan-Meyer estimates of the lifetime distributions were obtained by pooling five bioassays (40 bees per bioassay) for each treatment. The standard errors ranged from 0.0 to $1.4 \%$ for the control treatment, from 0.0 to $1.5 \%$ for the water treatment and from 0.0 to $2.6 \%$ for the Bt-toxin treatment.
$11.5 \%$ of the diet mass, each worker larva ingests approximately $4.1 \mathrm{mg}$ of pollen during its development. Assuming that each larva will feed only on pollen from $\mathrm{Bt}$ cotton plants, each larva will ingest $2.5 \mathrm{ng}$ of Cry1Ac toxin. However, because the proportion of toxin expressed in the cotton pollen varies with the plant variety, age, and environmental factors (Dong and $\mathrm{Li}$ 2007), $1.8 \mu \mathrm{g}$ of CrylAc were provided per larva in the bioassays. This amount represents a substantial excess relative to the estimate of the probable ingestion and further exaggerates the worst-case scenario.

\subsection{Cry1Ac toxicity to worker larva of T. spinipes}

The survival curves obtained from the KaplanMeier estimates indicate a low but significant larval mortality with development. In the control treatment (pure larval diet) only $9 \%$ of bees died before emergence (standard error (SE) ranging from 0.0 to $1.4 \%$, Figure 2). The addition of water to the diet increased this level of mortality $\left(\chi^{2}=22.7, d f=2\right.$, $P<0.001$, SE ranging from 0.0 to $1.5 \%$, Figure 2). Therefore, the addition of water to the diet to administer the CrylAc toxin caused a small but significant increase in larval mortality. The toxin itself did not significantly interfere with the survival of worker larvae and pupae throughout their development (SE ranging from 0.0 to $2.6 \%$, Figure 2). The evidence for this finding is that the values of survival on the diluted diet with and without Cry1Ac were similar $\left(\chi^{2}<0.001, d f=1\right.$, $P=0.99$, Figure 2).

The $T$. spinipes larvae fed the diets with and without Cry1Ac did not exhibit significant developmental differences $\left(F_{2,12}=0.13, P=0.7\right)$. The mean developmental duration for all animals was of $16.99 \pm 0.05$ days. The pupae from different treatments did not exhibit significant developmental differences $\left(F_{2,12}=0.013, P=0.98\right)$. The mean developmental duration for all pupae was of 17.09 \pm 0.08 days. In addition, no significant differences were observed for the body mass $\left(F_{2,12}=0.15\right.$, $P=0.86)$, the head width $\left(F_{2,12}=0.13, P=0.95\right)$, or the intertegular distance $\left(F_{2,12}=0.066, P=0.93\right)$ of the newly emerged workers. The mean body mass 
for all newly emerged workers was of $19.49 \pm$ $0.06 \mathrm{~mm}$, the mean head width was of $2.58 \pm$ $0.03 \mathrm{~mm}$ and the mean intertegular distance was of $1.50 \pm 0.02 \mathrm{~mm}$. The body mass was positively correlated with the morphometric traits, and these traits were positively correlated with each other (Table I).

\section{DISCUSSION}

The results of this study do not support the hypothesis that the ingestion of the CrylAc toxin is harmful to T. spinipes larvae. No toxic effect was observed, even at the high concentration of toxin in the diet provided to the larvae. This concentration was far greater than the probable concentration that would be ingested in the field, even considering a worst-case scenario in which GM cotton expressed this Bt toxin (Greenplate 1997; Han et al. 2010). Therefore, it is very unlikely that the larvae of this bee species will suffer any harm from the ingestion of cotton pollen expressing the Cry1Ac toxin. Our results are consistent with those previously found for the larvae of the honey bee A. mellifera and the solitary bee Osmia bicornis Linnaeus (Hanley et al. 2003; Babendreier et al. 2004; Lehrman 2007; Konrad et al. 2008; Lima et al. 2011). Furthermore, toxicological studies of adults of the honey bee A. mellifera, Bombus spp., and $O$. bicornis did not detect either lethal or sublethal effects of ingested Cry toxins (Morandin and Winston 2003; Duan et al. 2008; Babendreier et al. 2008; Konrad et al. 2009; Han et al. 2010).

The rearing protocol used for the worker larvae of $T$. spinipes was suitable and allowed high levels of adult emergence without malformation. For the first time, eggs were used to rear a stingless bee species for a toxicity bioassay. This approach allowed better standardization of age and diet ingestion among individuals. In turn, this information allowed more precise age determination and comparative assessment of the different treatments. The rearing method described has the potential for use in toxicity bioassays for toxins, pesticides, and even pathogens against other stingless bee species based on a proper adaptation of the size of the artificial brood chamber and amount of diet provided. However, the toxins should be added directly to the diet (i.e., without water dilution) because the addition of only a small amount of water to administer and distribute the toxin in the larval diet caused a significant increase in larval mortality. The contamination of the water by microorganisms (particularly fungi) constitutes a problem for larval rearing and a potential explanation of the negative effect of the addition of water to the diet of the stingless bee larvae. However, such contamination is very unlikely to have affected our study because we used only double-distilled (sterile) water. Therefore, the reason for the small negative effect of the added water on larval survival remains unclear.

Our study was the first to investigate the potential harmful effects of a toxin from a GM crop on the larvae of a stingless bee species. The majority of the experiments performed to date with GM plant toxins were conducted on adult bees. However, stingless bee larvae ingest greater amounts of pollen than do adults. As a result, they face a greater risk of high exposure to GM-contaminated pollen. Furthermore, the importance of toxicological studies with bee larvae is evident because high levels of larval mortality prevent replacement of the adult workers and cause the colony to decline rapidly.

Our results did not indicate that CrylAc toxin poses a significant risk to $T$. spinipes. However,

Table I. Correlations between body mass and morphometric traits of newly emerged workers of the stingless bee $T$. spinipes $(n=15)$.

\begin{tabular}{|c|c|c|c|c|}
\hline \multirow[t]{2}{*}{ Variables } & \multicolumn{2}{|c|}{ Head width } & \multicolumn{2}{|c|}{ Intertegular distance } \\
\hline & $r$ & $P$ value & $r$ & $P$ value \\
\hline Body mass & 0.92 & $<0.001$ & 0.91 & $<0.001$ \\
\hline Head width & - & - & 0.90 & $<0.001$ \\
\hline
\end{tabular}


future studies should explore potential behavioral alterations in adult workers subjected to the ingestion of the toxin during development. These studies are needed, although the evidence that such alterations occur is scarce and controversial (e.g., Ramirez-Romero et al. 2008). Fieldexposure experiments should be an additional focus of attention. Such experiments would allow a more comprehensive risk assessment of GM plants visited by stingless bees, although such risk appears negligible based on our results.

\section{ACKNOWLEDGMENTS}

We thank the members of the EMBRAPA Genetic Resources and Biotechnology Center, especially Drs. E. Fontes and E. Sujii, for fruitful discussions. Comments by Professor S.C. Dias, Catholic University of Brasília, substantially improved the first version of the manuscript. We also acknowledge E. Y. T. Nakasu and M. S. Lara for helping to rear the caterpillars and the stingless bee larvae. The comments and suggestions provided by the editor and two anonymous reviewers were greatly appreciated. The study was sponsored by the National Council of Scientific and Technological Development $(\mathrm{CNPq})$ and the Minas Gerais State Foundation for Research Aid (FAPEMIG).

Pas d'effets létal ou sublétal de la toxine-Bt Cry1Ac observés sur les larves de l'abeille sans aiguillon, Trigona spinipes

Toxine de Bacillus thuringiensis / plante transgénique / impact environnemental / pollinisateur indigène / évaluation des risques

Cry1Ac Bt-toxin hat keine letalen oder subletalen Effekte auf Larven der stachellosen Biene Trigona spinipes

Bacillus thuringiensis-Toxin / transgene Pflanzen / Umwelteinwirkung / einheimische Bestäuber / Risikoabschätzung

\section{REFERENCES}

Allison, P.D. (1998) Survival analysis using the SAS System - a practical guide. SAS Institute, Cary

Almeida, M.C., Laroca, S. (1988) Trigona spinipes (Apidae, Meliponinae): taxonomia, bionomia e relações tróficas em áreas restritas. Acta Biol. Par. 17, 67-108
Arpaia, S., Imperatriz-Fonseca, V.L., Pires, C.S.S., Silveira, F.S. (2006) Non-target and biodiversity impacts on pollinators and flower visiting insects. In: Hilbeck, A., Andow, D., Fontes, E. (eds.) Environmental risk assessment of genetically modified organisms: methodologies for assessing $\mathrm{Bt}$ cotton in Brazil, pp. 155-174. CABI, Cambridge

Babendreier, D., Kalberer, N., Romeis, J., Fluri, P., Bigler, F. (2004) Pollen consumption in honey bee larvae: a step forward in the risk assessment of transgenic plants. Apidologie 35, 293-300

Babendreier, D., Reichhart, B., Romeis, J., Bigler, F. (2008) Impact of insecticidal proteins expressed in transgenic plants on bumblebee microcolonies. Entomol. Exp. Appl. 126, 148-157

Bosch, J., Vicens, N. (2002) Body size as an estimator of production costs in a solitary bee. Ecol. Entomol. 27, 129-137

Buschini, M.L.T., Campos, L.A.O. (1995) Caste determination in Trigona spinipes (Hymenoptera, Apidae): influence of the available food and the juvenile hormone. Rev. Bras. Biol. 55, 121-129

Cerda, H., Sayyed, A.H., Wright, D.H. (2003) Laboratory culture conditions affect stability of resistance to Bacillus thunrigiensis Cry1 Ac in Plutella xylostella (Lep., Plutellidae). J. Appl. Entomol. 127, 142145

Dick, C.W. (2001) Habitat change, African honeybees and fecundity in the Amazonian tree Dinizia excelsa (Fabaceae). In: Bierregaard, R.O., Gascon, C., Lovejoy, T.E., Mesquita, R. (eds.) Lessons from Amazonia: the ecology and conservation of a fragmented forest, pp. 146-157. Yale University Press, New Haven

Dong, H.Z., Li, W.J. (2007) Variability of endotoxin expression in Bt transgenic cotton. J. Agron. Crop. Sci. 193, 21-29

Duan, J.J., Marvier, M., Huesing, J., Dively, G., Huang, Z.Y. (2008) A meta-analysis of effects of Bt crops on honey bees (Hymenoptera: Apidae). PLoS One 3, e1415. doi:10.1371/journal.pone.0001415

Greenplate, J.T. (1997) Response to reports of early damage in 1996 commercial Bt-transgenic cotton $\left(\right.$ Bollgard $\left.^{\circledR}\right)$ plantings. Soc. Invertebr. Pathol. Newsl. 29, $15-18$

Han, P., Chang-Ying, N., Chao-Liang, L., Jin-Jie, C., Desneux, N. (2010) Quantification of toxins in a Cry $1 \mathrm{Ac}+\mathrm{CpTI}$ cotton cultivar and its potential effects on the honey bee Apis mellifera L. Ecotoxicology 19, 1452-1459

Hanley, A.V., Huang, Z.Y., Pett, W.L. (2003) Effects of dietary transgenic Bt corn pollen on larvae of Apis mellifera and Galleria mellonela. J. Apic. Res. 42, 77-81

James, C. (2011) Global Status of Commercialized Biotech/GM Crops: 2011. ISAAA Brief No. 43. ISAAA, Ithaca

Klein, A.M., Vaissiere, B.E., Cane, J.H., Steffan-Dewenter, I., Cunningham, S.A., Kremen, C., Tscharntke, T. 
(2007) Importance of pollinators in changing landscapes for world crops. Proc. Soc. Lond. B. Biol. 274, 303-313. doi:10.1098/rspb.2006.3721

Klostermeyer, E.C., Mech, S.J., Rasmussen, W.B. (1973) Sex and weight of Megachile rotundata (Hymenoptera: Megachilidae) progeny associated with provision weights. J. Kansas Entomol. Soc. 46, 536-548

Konrad, R., Ferry, N., Gatehouse, A.M.R., Babendreier, D. (2008) Potential Effects of oilseed rape expressing oryzacystatin-1 (OC-1) and of purified insecticidal proteins on larvae of the solitary bee Osmia bicornis. PLoS One 3, e2664. doi:10.1371/journal. pone.0002664

Konrad, R., Connor, M., Ferry, N., Gatehouse, A.M.R., Babendreier, D. (2009) Impact of transgenic oilseed rape expressing oryzacystatin-1 (OC-1) and of insecticidal proteins on longevity and digestive enzymes of the solitary bee Osmia bicornis. J. Insect Physiol. 55, 305-313

Lehrman, A. (2007) Does pea lectin expressed transgenically in oilseed rape (Brassica napus) influence honeybee (Apis mellifera) larvae? Environ. Biosaf. Res. 6, 1-8

Lichtenberg, E.M., Hrncir, M., Turatti, I.C., Nieh, J.C. (2011) Olfactory eavesdropping between two competing stingless bee species. Behav. Ecol. Sociobiol. 65, 763-774

Lima, M.A.P., Pires, C.S.S., Guedes, R.N.C., Nakasu, E.Y.T., Lara, M.S., Fontes, E.M.G., Sujii, E.R., Dias, S.C., Campos, L.A.O. (2011) Does Cry1Ac BT-toxin impair development of worker larvae of Africanized honey bee? J. Appl. Entomol. 135, 415-422

Malone, L.A., Tregidga, E.L., Todd, J.H., Burgess, E.P.J., Philip, B.A., Markwick, N.P., Poulton, J., Christeller, J.T., Lester, M.T., Gatehouse, H.S. (2002) Effects of ingestion of a biotin-binding protein on adult and larval honey bees. Apidologie 33, 447-458

Malone, L.A., Todd, J.H., Burgess, E.P.J., Christeller, J.T. (2004) Development of hypopharyngeal glands in adult honey bees fed with a Bt toxin, a biotinbinding protein and a protease inhibitor. Apidologie 35, 655-664

Morandin, L.A., Winston, M. (2003) Effects of novel pesticides on bumble bee (Hymenoptera: Apidae) colony health and foraging ability. Environ. Entomol. 32, 555-563

Motulsky, H.J. (2007) Prism 5 Guide. GraphPad Software, San Diego
Nieh, J.C., Barreto, L.S., Contrera, F.A.L., ImperatrizFonseca, V.L. (2004a) Olfactory eavesdropping by a competitively foraging stinglees bee, Trigona spinipes. Proc. R. Soc. Lond. B. 271, 1633-1640

Nieh, J.C., Contrera, F.A.L., Yoon, R.R., Barreto, L.S., Imperatriz-Fonseca, V.L. (2004b) Polarized short odor-trail recruitment communication by a stingless bee, Trigona spinipes. Behav. Ecol. Sociobiol. 56, $435-448$

Nieh, J.C., Kruizinga, K., Barreto, L.S., Contrera, F.A.L., Imperatriz-Fonseca, V.L. (2005) Effect of group size on the agression strategy of an extirpating stingless bee, Trigona spinipes. Insectes Soc. 52, 147-154

Pyke, G.H. (1978) Optimal body size in bumblebees. Oecologia 34, 255-266

Quezada-Euán, J.J.G., Lopez-Velasco, A., Perez-Balam, J., Moo-Valle, H., Velazquez-Madrazo, A., Paxton, R.J. (2011) Body size differs in workers produced across time and is associated with variation in the quantity and composition of larval food in Nannotrigona perilampoides (Hymenoptera, Meliponini). Insectes Soc. 58, 31-38

Ramirez-Romero, R., Desneux, N., Decourtye, A., Chaffiol, A., Pham-Delegue, M.H. (2008) Does Cry $1 \mathrm{Ab}$ protein affect learning performances of the honey bee Apis mellifera L. (Hymenoptera, Apidae)? Ecotoxicol. Environ. Saf. 70, 327-333

Sakagami, S.F. (1981) Stingless Bees. In: Hermann, H.R. (ed.) Social insects, vol. 3. Academic, New York

SAS Institute (2008) SAS/STAT user's guide. SAS Institute, Cary, NC, USA

Slaa, E.J., Chaves, L.A.S., Malagodi-Braga, K.S., Hofstede, F.E. (2006) Stingless bees in applied pollination: practice and perspectives. Apidologie 37, 293-315

Velthuis, H.H.W., Cortopassi-Laurino, M., Pereboom, Z., Imperatriz-Fonseca, V. (2003) Speciation, development, and the conservative egg of the stingless bee genus Melipona. Proc. Sect. Exp. Appl. Entomol. 14, 53-57

Wcislo, W.T., Cane, J.H. (1996) Floral resource utilization by solitary bees (Hymenoptera: Apoidea) and exploitation of their stored foods by natural enemies. Annu. Rev. Entomol. 41, 257-286

Wilkinson, M.J. (2004) Abandoning 'responsive' GM risk assessment. Trends Biotechnol. 22, 438-439 